University for Business and Technology in Kosovo

UBT Knowledge Center

UBT International Conference

2015 UBT International Conference

Nov 7th, 9:00 AM - 5:00 PM

\title{
Architecture in verses of Professor Bashkim Fehmiu
}

Arbër Sadiki

University for Business and Technology, arber.sadiki@gmail.com

Follow this and additional works at: https://knowledgecenter.ubt-uni.net/conference

Part of the Architecture Commons

\section{Recommended Citation}

Sadiki, Arbër, "Architecture in verses of Professor Bashkim Fehmiu" (2015). UBT International Conference. 60.

https://knowledgecenter.ubt-uni.net/conference/2015/all-events/60

This Event is brought to you for free and open access by the Publication and Journals at UBT Knowledge Center. It has been accepted for inclusion in UBT International Conference by an authorized administrator of UBT Knowledge Center. For more information, please contact knowledge.center@ubt-uni.net. 


\title{
Architecture in verses of Professor Bashkim Fehmiu
}

\author{
Arbër Sadiki \\ UBT, Faculty of Architecture and Spatial Planning, Prishtina, KOSOVO \\ University of Belgrade, Faculty of Architecture, Belgrade, SERBIA \\ arber.sadiki@gmail.com
}

\begin{abstract}
The contribution of architect Bashkim Fehmiu as one of important personalities in Kosovo in second half of 20th century, includes many areas such as: academic as professor at the Faculty of Architecture at the University of Prishtina, administrative, as founder of Prishtina Institute of Urbanism, contribution in the urban planning as the author of many urban plans of Prishtina, and his architectural contribution as the author of several important buildings of this period. Even his work in above mentioned areas is not still investigated, analyzed, classified, documented and published, nonetheless is recognized by many people, maybe as result of short time between the period of his active contribution with nowadays.

This paper aims to initiate illumination of one another dimension of his multidimensional personality, his poetic dimension. In this paper is analyzed "Poem of Architecture" ("Poemza e arqitekturës") written in 1954 during his studies in Belgrade, unpublished until now, where he expressed his feelings, love, his views and vision on architecture.
\end{abstract}

Key words: Bashkim Fehmiu, Poem of Architecture

\section{Introduction}

Interrelation between literary genres and architecture is not something new. On the contrary, be it in prose, poetry or drama, architecture is always unconsciously present as a setting in which events take place or else as an artistic purpose in itself to enrich the aesthetic value of the literary genre. We find that since the beginnings of literature, beginning from Greek literature in "Odyssey" by Homer, by having Odyssey's detailed depiction of his house after returning from his journey ${ }^{21}$. Cicero, Virgil, and many other Roman writers, in different ways, have brought to us the image of Rome, its splendour and fall, its hope and despair. [1] No other person contributed more than Victor Hugo by his "Cathedral of Paris" to the transformation of that building into a symbol of French nation, just about when it was losing its architectural splendour.

In Albanian literature it could not be otherwise. De Rada in "Këngët e Milosaos" (Songs of Milosao), Migjeni in "Novelat e qy tetit të Veriut" (Novels From the Northern City) depict the imagery of cities or further by Faik Konica in "Doktor Gjilpëra"22 (Doctor Needle) where for the first time in the Albanian modern literature, the relationship between the city and the citizen has been portrayed, in this case, that of Durrës and Tirana in the second decade of the twentieth century. In addition Ernest Koliqi in his "Hija e maleve" 23 (Shadow of the Mountains) through profile inconsistency of citizens compared to the city, as a matter of fact through literary genre, tackled a typical subject matter of urban sociology, a theme reinforced even more in "Tregtar flamujsh" 24 (Trader of Flags) by the same author.

This paper is not aimed to contribute to the argument of this undisputable interrelation, nor to deal with the analysis of literary works whose authors are architects, e.g. Poems of Michelangelo or Albert's or those of Petraq Kolevica in the Albanian case. The aim of this paper is to draw attention

${ }^{21}$ Homer, $9^{\text {th }}$ century BC “Odyssey”, Song XXIII.

22 "Doktor Gjilpëra", written and published in "Dielli” newspaper in 1924.

23 "Hija e Maleve", a collection of 12 novels published in 1929 in Zadar, Croatia.

24 "Tregtar flamujsh", collection of 16 novels, first published in 1935 in Tirana, Albania. 
to those literary works, the ultimate goal of which is the architecture, and which are not many in the world literature, and moreover quite not approached in the Albanian literature.

\section{2. "The Poem of Archite cture" ("Poemza e arqitekturës)}

The multidimensional contribution of Bashkim Fehmiu; professor, architect and urban planner, in the area of architecture and urban planning, although not studied, analyzed and published yet to the preferred level, is indisputable. His contribution begins with education as a professor at the Faculty of Architecture at the University of Prishtina; management and administration, as the founder and leader, initially of Technical Service of the Municipality of Prishtina and later the Institute of Urbanism of Prishtina, as well as the author of many urban and architectural contributions as the author of many urban and architectural plans of Prishtina in the second half of the twentieth century. [2]. Given that the abovementioned contribution appears as a result of a public profession, and also by the fact that the period of time between his professional activity and the time we are discussing about is relatively short, this contribution is generally acknowledged by the public. However, in this paper we are beginning to unfold a contribution of him, totally unknown so far, a contribution to architecture by the means of poetry. From the research conducted so far in his personal library, there are many manuscripts, among which a notebook of poems with an inscription on the cover "Bashkim Fehmiu II" which implies that there is at least one notebook before that, and perhap s, why not, many after it.

The poems in that notebook were written throughout the year 1954, at the time when Professor Bashkim was in the beginning years of his studies at the Faculty of Architecture in Belgrade. In the total of 61 poems, he sings to: the new day, dawn, beauty, music, future, wine, love ... Amongst them of course, the greatest passion of the author, the passion for architecture could not dwell without its song, to which he sings in the verses of "Poemza of arqitekturës".

In the total of 361 verses, he expressed his love for architecture, gave his definition to it, conducted an assessment of its historical development, defined its role in society and vice versa, gives his vision on its future development.

His fiery passion for architecture is expressed whence the first lines of the poem:
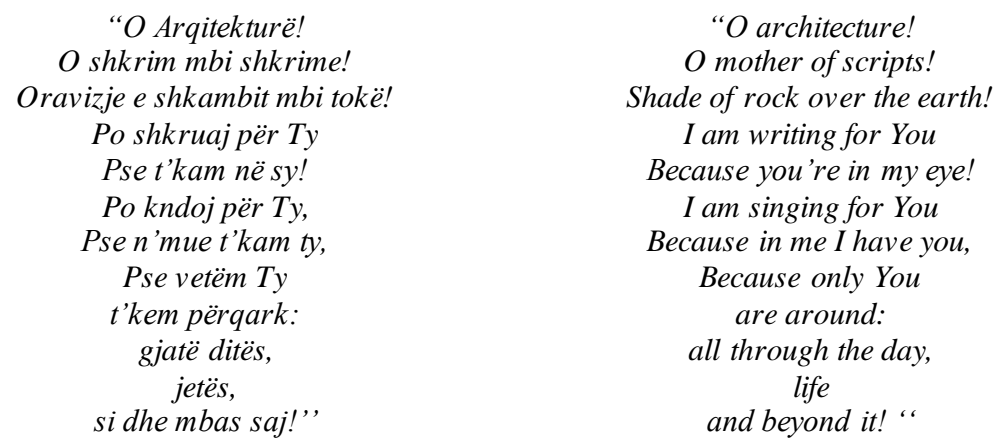

Although being at the beginning of his studies for architecture, he has the courage to provide his approach to it. He speaks about architecture, not in its narrow terms of engineering but as a profession that deals with the environment in correlation with human psychology.

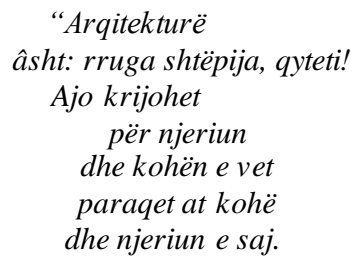

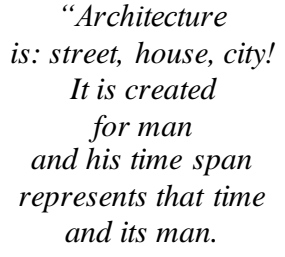




$$
\begin{gathered}
\text { Ajo âsht pjesë } \\
\text { e jetës sonë } \\
\text { e kulturës sonë } \\
\text { e epokës sonë }
\end{gathered}
$$

$$
\begin{aligned}
& \text { That is part } \\
& \text { of our life } \\
& \text { of our culture } \\
& \text { of our era" }
\end{aligned}
$$

At this point, we are within the insights and definitions by Ludwig Mies van der Rohe expressed since 1924 , according to whom "the architecture expresses the will of an era manifested in space". ${ }^{25}$

In the following verses, he speaks of the great importance of doing quality architecture, because, unlike low quality book, music and painting which can be avoided, the architecture being manifested in space, unavoidably is imposed to every one. At this point we see the concurrence with the principles of Bruno Zevi on the need to draw attention to architecture because it is every where and belongs to every one. $^{26}$

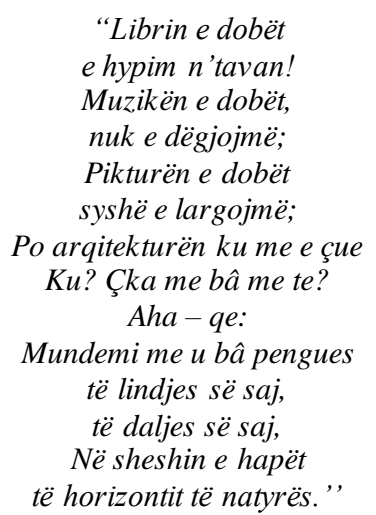

\author{
"Bad book \\ under the roof we take it! \\ Bad music, \\ we do not listen to it; \\ Bad painting \\ away from our sight will be taken; \\ But architecture where shall be taken \\ Where? Do what with? \\ A-ha-this: \\ We can be impediment \\ of its birth, \\ of its advent, \\ At the open square \\ of nature horizon "
}

For Professor Bashkim, the architecture is closely associated with the society. It directly affects the shaping and education of it, and as such it should be created by taking into account the will of society. Architecture does not belong only to the architects therefore it cannot, and should not depend only on them.
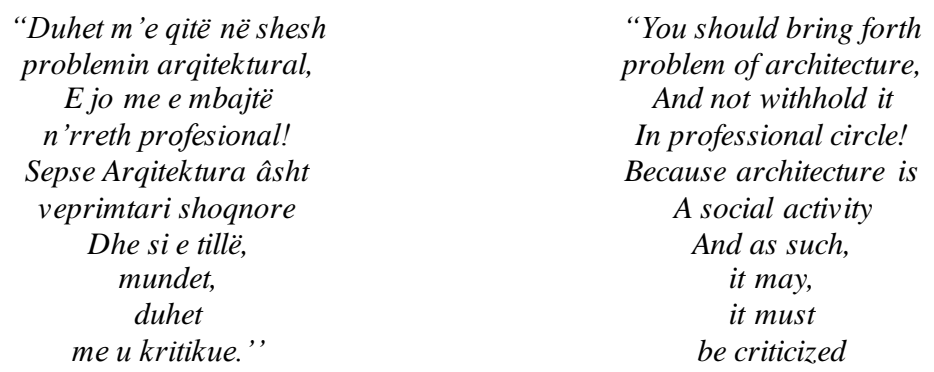

The author ends the poem with the same fiery passion he begins it. He compares it to the basic elements of life. To him the architecture is food, water and air.

$$
\begin{array}{rr}
\text { "Arqitektura âsht } & \text { "Architecture is } \\
\text { dhunti e madhe } & \text { a great gift } \\
\text { e natyrës, } &
\end{array}
$$

${ }^{25}$ Mies van der Rohe, “Der Querschnitt”, 1924. Translated from German by Philip Johnson. Museum of Modern Art. New York, NY: 1947

${ }^{26}$ Bruno Zevi (1918-2000), Italian architect, professor and writer. In 1948 he published the book "Saper vedere l'architettura" which was reprinted over 20 times. For the first time in English was published in 1957 in New York, by Horizon Press under the title "Architecture as Space: How to Look at Architecture”, translated by Milton Gendel. 


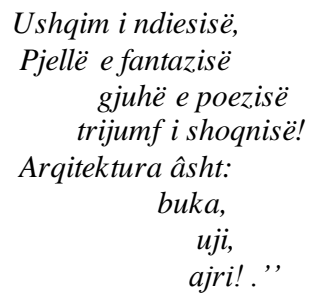

of nature,

Food of feeling

Fantasy offspring

language of poetry

triumph of society!

Architectures is:

food,

water,

air! ."

\title{
3. Similarities to "The Poem of the Right Angle" by Le Corbusier(1955)
}

Firstly it should be clarified that we cannot talk here about influence, because "The Poem of Architecture" was written in 1954, while "Poem of the Right Angle" by Le Corbusier ("Le Poeme de l'Angle Droit") even though was written during the years 1943-53, it was published in 1955. Also at the outset, it should be noted that the first case is about an author who was in the beginning of his studies for architecture while the second case is about an author at the peak of his professional maturity.
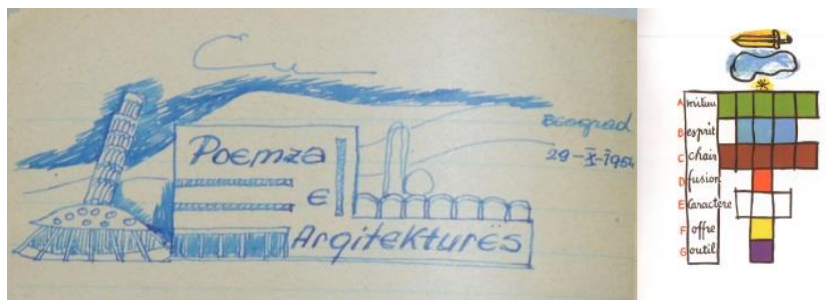

Fig.1. Illustration from "The poem of Architecture" (left) and "Poem of the Right Angle" (right) At first, that what is common to these two poems is the topic they explore, that is the architecture. Verses are accompanied by illustrations same as in the first case as well as in the second. In both cases, the authors express the love and passion they have for architecture, they express their approaches towards architecture, its role in society and also the role of society on architecture. Le Corbusier always associates architecture with the sunlight, while the light and the sun with the taxonomy of our natural rhythm, whereas for Professor Bashkim the architecture is food, air and water.

\author{
"...the two rhythms \\ which regulate our destiny: \\ A sun rises \\ A sun sets $A$ sun rises again", 27
}

27 "Le Poeme de l'angle droit" consists of a total of 19 poems accompanied with as many illustrations. All illustrations are based on the classic rules of alchemy where his compositions through color codes read the core of the content through dialectics of alchemy. Therefore the use of green at the poetry "Envirenment" a color which in codes of alchemy symbolizes the primary matter of the universe, Le Corbusier expresses visually the inseparable link between light, nature and the universe with the rhythm of daily life. 


\section{Conclusion}

"Every great architect is - necessarily - a great poet. He must be a great original interpreter of his time, his day, his age."

Frank Lloyd Wright

The approaches of the author towards architecture expressed through verses, although often influenced by world architects and theoreticians of the time, are an indicator of his orientation towards his professional development since the time he was a student.

Bashkim Fehmiu through "Poemzës së arqitekturës" (The Poem of Architecture) confirms once again the statement of the architect Frank Lloyd Right that every architect must also necessarily be a good poet. The content of the poem and its treatment by using a rich poetic language, the rhythm in the verse and the poem as a whole, imply that we are dealing with a gifted author for poetry, subsequently for architecture.

All these evidence coming to us from the time of his first years of studying architecture are the best indicator that in the years to come, thanks to his own persistent commitment, where architecture did not represent only his profession but also the mission of his life, he would become an admirable architect, urban planner, professor and intellectual of the second half of the twentieth century in Kosovo.

Similarities with the "The Poem of the Right Angle" by Le Corbusier appear as a prophecy that enunciates the future personality who in fact represents Kosovo's Le Corbusier.

\section{References}

1. Edwards, C.: Writing Rome, Textual Approaches to the City, Cambridge University Press, Cambridge (1996)

2. Sadiki, A.: The Contribution of the Architect Bashkim Fehmiu in the Architecture of Prishtina after the Second World War, International Conference of Applied Sciences I, 8-9 May, Tetovo (2015)

\section{Source of images}

Fig.1. Personal Archive of Professor Bashkim Fehmiu, "Mother Teresa" Boulevard, "Fehmi Agani" str., IV ${ }^{\text {th }}$ floor, apartment no.5. 